\title{
PERTANGGUNGJAWABAN PIDANA TERHADAP PELAKU TINDAK PIDANA PEMALSUAN DOKUMEN BERUPA SURAT TANDA NOMOR KENDARAAN (STNK) (Studi Putusan Nomor 241/PID.B/2021 PN Gns)
}

CRIMINAL LIABILITY AGAINST CRIMINAL ACTS OF DOCUMENT FALSIFICATION IN THE FORM OF VEHICLE NUMBER MARK (STNK) (Study of Decision Number 241/PID.B/2021 PN Gns)

\author{
Reza Sedyadi ${ }^{1}$ Baharudin $^{2}$, Anggalana ${ }^{3}$ \\ Universitas Bandar Lampung \\ Jl. ZA Pagar Alam No 26, Labuhan Ratu, Kecamatan Labuhan Ratu, Kota \\ Bandar Lampung \\ Email : reza.18211199@student.ubl.ac.id
}

$\begin{array}{ll}\text { Submission } & : \text { 17 Januari } 2022 \\ \text { Accepted } & : \text { 25 Januari } 2022 \\ \text { Publish } & : \text { 31 Januari } 2022\end{array}$

\begin{abstract}
Among various types of criminal acts in the community, falsification of letters becomes one of the criminal acts that are rife. For examples criminal cases of falsification of letters are contained in Number: 241/PID.B/2021 PN GNS. Defendant I Suradal and defendant II Efan Efendi committed the criminal act of falsifying documents in the form of STNK. In this study focus on the problem: (1) What are the factors supporting criminal offenders committing STNK counterfeiting crimes? (2) How is the accountability of the perpetrators of STNK counterfeiting? (3) How is the judge's consideration of the perpetrators of STNK counterfeiting? In this study apply normative juridical approaches as well as empirical juridical. The process of data collection is carried out by field study steps as well as literature studies. The data obtained is then analyzed with qualitative techniques to reach conlcusions in the research conducted. In this study produced answers about what are the factors that cause the perpetrator to commit the crime of forgery, how the perpetrator is responsible and how the judge's consideration of the perpetrator of the STNK forgery in Number: 241/PID.B/2021 PN GNS.
\end{abstract}

Keywords: Criminal Responsinility, Forgery Criminal Act, Forgery STNK. 


\begin{abstract}
Abstrak
Diantara berbagai macam jenis tindak pidana di masyarakat, pemalsuan surat menjadi salah satu tindak pidana yang marak terjadi. Contoh kasus tindak pidana pemalsuan surat terdapat dalam Putusan Nomor: 241/PID.B/2021 PN Gns. Terdakwa I Suradal dan Terdakwa II Efan Efendi melakukan tindak pidana pemalsuan dokumen berupa STNK. Dalam penelitian ini menitik fokuskan dalam permasalahan: (1) Apa saja yang menjadi faktor pendukung pelaku tindak pidana melakukan tindak pidana pemalsuan STNK? (2) Bagaimana pertanggungjawaban pelaku tindak pidana pemalsuan STNK? (3) Bagaimana pertimbangan hakim terhadap pelaku tindak pidana pemalsuan STNK?. Pada penelitian ini mengaplikasikan pendekatan yuridis normatif serta yuridis empiris. Proses pengumpulan data dilakukan dengan langkah studi lapangan serta studi kepustakaan. Data yang diperoleh kemudian dianalisis dengan teknik kualitatif untuk mencapai kesimpulan dalam penelitian yang dilakukan. Dalam penelitian ini menghasilkan jawaban tentang apa saja faktor yang menyebabkan pelaku melakukan tindak pidana pemalsuan, bagaimana pertanggungjawaban pelaku dan bagaimana pertimbangan hakim terhadap pelaku tindak pidana pemalsuan STNK dalam Putusan Nomor: 241/PID.B/2021 PN Gns.
\end{abstract}

Kata Kunci: Pertanggungjawaban pidana, Tindak Pidana Pemalsuan, Pemalsuan STNK.

\title{
A. Pendahuluan
}

Sesuai dengan syarat yang berlaku dalam Undang-Undang 1945 Negara Kesatuan Republik Indonesia ialah Negara Hukum. Perihal tersebut dipercaya sebagai perlengkapan untuk memberikan kesetaraan dan keadilan dalam bermasyarakat guna mewujudkan warga Negara yang adil dan makmur berlandaskan Pancasila.

Munculnya peraturan atau hukum salah satunya disebabkan oleh adanya sumber daya manusia atau masyarakat (ubi-us ubi-societas). Peraturan atau hukum bermanfaat untuk memenuhi rasa damai dan kerukunan untuk setiap warga Negara. Negara Republik Indonesia menjunjung setinggi-tingginya hukum selaku alat pembatas supaya tercipta perdamaian serta kerukunan dalam bermasyarakat, berbangsa serta bernegara. Bisa ditegaskan bahwa Indonesia menjalankan Negara bukan hanya berlandaskan pada kekuasaan. 
Situasi tersebut bertujuan supaya tiap masyarakarat menjadi masyarakat yang sada setiap warga Negara Indonesia menjadi warga Negara yang paham akan hukum dan bermanfaat untuk mewujudkan cita-cita Negara Kesatuan Republik Indonesia sebagaimana yang telah diamanatkan pada Alinea keempat Pembukaan Undang-Undang Dasar 1945. Seiring terciptanya peraturan atau hukum di Indonesia maka akan tercipta juga pelanggaran hukum. Adanya peraturan hukum akan terlahir pula suatu kejahatan atau tindak pidana. Aparat penegak hukum menjadi salah satu elemen yang bertanggung jawab guna menciptakan hukum yang stabil. Indonesia sebagai Negara yang berkembang tentunya tidak dapat dipisahkan dari pengaruh globalisasi. Pengaruh dari globalisasi itu sendiri sudah merambah ke berbagai aspek kehidupan. Perkembangan tersebut dapat memberikan dampak terhadap mobilitas kehidupan masyarakat sehingga timbul pergeseran budaya yang sangat signifikan dalam lingkungan bermasyarakat.

Seiring berjalannya masa, globalisasi juga memiliki peran dalam tumbuhnya tindak kejahatan pidana dalam kehidupan bermasyarakat. Pada decade ini pelanggaran dan tindak kejahatan yang terjadi dimasyarakat semakin meningkat dan tidak bisa dipungkiri keberadaannya. Tindak kejahatan yang marak yaitu salah satunya dipengaruhi faktor ekonomi. Tindak kejahatan sendiri merupakan tingkah laku individu maupun kelompok yang merugikan orang lain. Menurut asalnya tidak ada campur tangan penguasa terhadap tindak kejahatan melainkan semata-mata dipandang sebagai persoalan individu atau keluarga. ${ }^{1}$

Hukum Pidana sebagai peraturan yang mengatur tentang gerak-gerik yang boleh dilarang dengan menggunakan peraturan-peraturan dan akibat-akibatnya di dalam kegunaan hukuman bagi orang-orang yang melakukannya dan memenuhi faktor-faktor gerak yang tercantum dalam Hukum Pidana. Seperti perbuatanperbuatan yang dilarang dalam KUHP, UU Tipikor, UU HAM dan sebagainya.

${ }^{1}$ I.S Susanto, Kriminologi, cet. Ke 1, (Yogyakarta: Genta Publising, 2011), hlm 22. 
Peraturan pidana adalah peraturan yang mengatur tentang gerak-gerik apa yang dilarang dan memberikan hukuman bagi individu yang melanggarnya. Sementara Dr. Abdullah Mabruk An-Najar dalam bukunya "Pengantar Ilmu Hukum" mendiktekan definisi peraturan penjahat sebagai "seperangkat kebijakan penjara yang memutuskan tindakan penjahat yang mungkin dilarang dengan menggunakan peraturan, konsekuensi bagi individu yang melakukannya itu, siasat yang harus dilampaui dengan menggunakan peraturan terdakwa dan persidangannya, di samping hukuman yang dijatuhkan kepada terdakwa. ${ }^{2}$

Pelaku tindak pidana bermacam-macam jenisnya mulai dari lingkungan sosial sehari-hari hingga penegakan hukum. Salah satu kejahatan yang sudah tidak asing lagi yang terjadi di masyarakat adalah kejahatan pemalsuan. Tindak pidana pemalsuan itu diatur dalam KUHP Pasal 263 sampai dengan 267. Tindak pidana pemalsuan biasanya pemalsuan surat, uang logam dan identitas.

Surat itu sendiri merupakan lembar kertas di atasnya tertulis sebuah kata, kata atau kalimat termasuk huruf atau angka yang dapat disusun dan dibuat melalui sarana teknik apapun yang memiliki arti ${ }^{3}$ Mengenai surat palsu, perlindungan dari Negara sangatlah diperlukan dikarenakan surat tersebut berbentuk tulisan dan siapa saja dapat mempercayainya. Akhir-akhir ini maraknya tindak pidana kejahatan jenis pemalsuan Surat Tanda Nomor Kendaraan (STNK) untuk motor dan sepeda motor. Dalam Pasal enam puluh lima ayat (2) UndangUndang Nomor 22 Tahun 2009 tentang Lalu Lintas dan Angkutan Jalan yang menyatakan bahwa: Sebagai bukti bahwa kendaraan bermotor telah didaftarkan, kepada pemilik diberikan buku pemilik kendaraan bermotor, surat tanda registrasi kendaraan bermotor. ${ }^{4}$

\footnotetext{
${ }^{2}$ Ali, M. 2017. Sistem Peradilan Pidana Progresif; Alternatif dalam Penegakan Hukum Pidana. Jurnal hukum Ius Quia Iustum, Vol.14, No. 2, hlm 2.

${ }^{3}$ Adami Chazawi dan Ardi Ferdian, Tindak Pidana Pemalsuan : Tindak Pidana Yang Menyerang Kepentingan Hukum Terhadap Kepercayaan Masyarakat mengenai Kebenaran Isi Tulisan dan Berita yang Disampaikan, (Jakarta: PT Rajawali Pers, 2014), hlm 135.

${ }^{4}$ Pasal 65 ayat (2) UU No. 22 Tahun 2009, Tentang Lalu Lintas dan Angkutan Jalan
} 
Seperti yang kita ketahui STNK sangat penting dalam hal kepemilikan kendaraan. Setiap prosedur yang berlaku harus diikuti untuk mendapatkan STNK yang asli dari pihak yang berwenang. Namun, alasan rumit membuat para pemilik mobil dan sepeda motor enggan mengikuti prosedur yang berlaku. Akibatnya, terciptanya oknum-oknum yang tidak bertanggung jawab hadir untuk memanfaatkan situasi tersebut demi keuntungan pribadi.

Kendaraan yang tidak mempunyai dokumen karena hilang ataupun dicuri tetapti tidak mau mengembalikannya kepada pihak dapat memunculkan tindak pidana kejahatan lain yang dapat mengakibatkan kerugian. Pemalsuan STNK salah satu nya bertujuan agar dapat menghindar dari pihak polisi jikalau sewaktuwaktu ada razia di jalan raya. Ketidakakuratan pihak polisi yang memeriksa saat razia berlangsung dapat menguntungkan mereka yang memalsukan STNK.

Di Lampung Tengah tepatnya di Kampung Surabaya Baru Kecamatan Surabaya terdapat kasus pemalsuan Surat Tanda Nomor Kendaraan (STNK). Kasus tersebut ditangani oleh Kantor Polisi Resor (Polres) Lampung Tengah karena pada waktu kejadian tersebut dilakukan di wilayah hukum Lampung Tengah. Tindak pidana pemalsuan STNK ini dilakukan oleh warga Kampung Surabaya Kabupaten Lampung Tengah yang bernama Efan Efendi dan Suradal. Efan Efendi dan Suradal melanggar Pasal 263 ayat (1) Kitab Undang-Undang Hukum Pidana.

Terdakwa I Efan Efendi bertindak bersama Terdakwa II Suradal. Berawal dari bulan November 2013, Terdakwa II Suradal belajar membuat STNK palsu di kediaman Terdakwa I Efan Efendi untuk konsumen dengan alat yang dimiliki seperti CPU, monitor, mouse, keyboard, kertas hvs dan lain-lain. Setelah belajar membuat STNK palsu, Terdakwa II merasa dirinya mulai bisa membuat STNK palsu terlihat seperti aslinya. Konsumen mengatakan STNK palsu tersebut hanya digunakan untuk mengambil uang ke leasing saja dan tidak dipergunakan untuk jalan. Kemudian konsumen merasa puas dengan hasil STNK palsu yang dibuat Terdakwa II Suradal tersebut, konsumen memberitahukan ke rekan-rekan nya 
bahwa ada jasa pembuatan STNK palsu maka pesanan pembuatan STNK palsu yang dilakukan Terdakwa I Efan Efendi dan Terdakwa II Suradal semakin ramai hingga tahun 2021 dengan ongkos sebesar Rp.25.000,- (dua puluh lima ribu rupiah) hingga Rp. 30.000,- (tiga puluh ribu rupiah). Sebelumnya kejadian ini telah dilaporkan oleh masyarakat bahwa telah adanya pemalsuan surat dan tanda tangan yang dilakukan oleh Terdakwa I dan Terdakwa II.

Para Terdakwa pada hari minggu tanggal 10 April 2021 ditangkap oleh anggota polisi dengan para saksi-saksi di kediaman Efan Efendi di Dusun IV Kampung Surabaya Baru Kecamatan Bandar Surabaya Kabupaten Lampung Tengah dan Suradal di Dusun II RT/RW Gaya Baru III Kecamatan Seputih Surabaya Kabupaten Lampung Tengah pada pukul 15.35 WIB. Dengan barang bukti handphone, keyboard, mouse, printer, screen lcd, printer, pc dan dokumen STNK palsu yang lainnya. Atas tindakan tersebut dapat diancam sebagaimana yang terdapat dalam KUHP Pasal 263 ayat (1).

Setiap laki-laki atau perempuan yang membuat berita acara yang kuat atau memalsukan surat yang dapat memberikan dorongan ke atas untuk suatu hak, suatu penyelesaian atau pelunasan utang atau yang dimaksudkan sebagai pembuktian sesuatu dengan maksud untuk dipergunakan atau memerintahkan kepada laki-laki atau perempuan lain. berlaku surat seolah-olah isinya sudah benar dan sekarang tidak lagi palsu, diancam jika penggunaan tersebut dapat menimbulkan kerugian karena pemalsuan surat dengan pidana penjara paling lama enam tahun. ${ }^{5}$

Berdasarkan uraian diatas, maka penulis mengangkat permasalahan sebagai berikut:

1. Apa saja faktor-faktor penyebab terdakwa melakukan tindak pidana pemalsuan dokumen berupa Surat Tanda Nomor Kendaraan (STNK) (Studi Putusan Nomor 241/PID.B/2021 PN Gns)

\footnotetext{
${ }^{5}$ Pasal 263, Kitab Undang-undang Hukum Pidana
} 
2. Bagaimana pertanggungjawaban pidana terhadap pelaku tindak pidana pemalsuan dokumen berupa Surat Tanda Nomor Kendaraan (STNK) (Studi Putusan Nomor 241/PID.B/2021 PN Gns)

3. Bagaimana pertimbangan hakim terhadap pelaku tindak pidana pemalsuan dokumen berupa Surat Tanda Nomor Kendaraan (STNK) (Studi Putusan Nomor 241/PID.B/2021 PN Gns)

Metode merupakan suatu cara yang tepat yang bertujuan untuk melakukan sesuatu dengan melibatkan pemikiran secara seksama untuk mencapai tujuan. Dalam penelitian ini menggunakan pendekatan masalah yaitu pendekatan yuridis normatif dan pendekatan empiris serta menggunakan statistics primer dan sekunder. Pendekatan dengan sudut pandang masalah hukum dijadikan sebagai kaidah yang dianggap sesuai dengan yuridis normatif. Dalam pendekatan yuridis normatif dilakukan library studies atau studi kepustakaan mengenai hal yang bersifat teoritis. Pendekatan empiris digunakan dengan cara mengamati secara actual atau fakta dari obyek dengan melakukan wawancara. Penelitian ini menggunakan analisis statistics secara kualitatif.

\section{B. Hasil Penelitian dan Pembahasan}

1. Faktor Penyebab Terdakwa Melakukan Tindak Pidana Pemalsuan Dokumen Berupa Surat Tanda Nomor Kendaraan (Stnk) (Studi Putusan Nomor 241/Pid.B/2021 Pn Gns)

Alasan aktivitas ilegal adalah elemen dalam dan luar. Unsur-unsur dalam adalah dorongan-dorongan yang timbul dari dirinya sendiri, walaupun unsurunsur luar merupakan unsur-unsur yang dibuat dari luar itu sendiri, unsur-unsur tersebut dapat dikatakan cukup rumit dan bervariasi. Ketimpangan sosial, ketimpangan moneter, ketidakadilan, dan lain-lain, adalah contoh-contoh penyebab perbuatan bajingan yang datang dari luar diri sendiri.

Pada unsur batin terdapat unsur akademik dan unsur laki-laki atau perempuan. Masalah sekolah merupakan salah satu penggunaan kekuatan bagi seseorang untuk mengabdikan diri secara melawan hukum. Hal ini disebabkan karena kurangnya pemahaman mereka tentang hal-hal serta kebijakan-kebijakan 
dalam tata cara gaya hidup di masyarakat.

Dalam unsur laki-laki atau perempuan, seseorang yang perilakunya ideal akan menyebabkan individu tersebut mendapatkan kesia-siaan dari masyarakat, namun sebaliknya jika seseorang berperilaku buruk akan menimbulkan kekacauan di masyarakat. Mereka dapat memanipulasi dan meningkatkan karakter yang baik mungkin mampu menghasilkan banyak keuntungan masingmasing untuk diri mereka sendiri dan orang lain.

Sementara itu, individu yang tidak dapat memanipulasi karakternya dan cenderung terombang-ambing melalui cara-cara kecenderungan akan tetap terseret mengikuti arus masa kini. Apakah itu benar atau mengerikan, mereka mungkin terus mengikutinya. Ada juga motif mengapa seseorang melakukan perbuatan melawan hukum karena tujuan manusia adalah hal-hal yang tidak ada batasnya.

Dilihat dari unsur luarnya, seseorang dapat melakukan perbuatan melawan hukum karena berbagai faktor antara lain unsur moneter, unsur lingkungan, unsur penegakan peraturan, dan unsur perbaikan dunia.

Kemiskinan merupakan fenomena yang tidak dapat dihindari dalam masyarakat di suatu negara. Hingga saat ini belum ada jalan keluar untuk mengatasi fenomena tersebut. Hampir setiap 12 bulan tingkat kebutuhan pokok terus meningkat, sementara pendapatan setiap orang tidak selalu mampu memenuhi kenaikan ini. Sehingga menjadi alasan bagi seseorang untuk melakukan tindak pidana.

Selain unsur keuangan, unsur lingkungan merupakan salah satu unsur yang memiliki kekuatan terhadap maraknya tindak pidana korupsi. seseorang yang tinggal di lingkungan yang membantu biaya kejahatan, maka pada suatu waktu ia juga dapat mencurahkan kejahatan. Banyak hal yang menjadikan lingkungan sebagai salah satu aspek dalam maraknya suatu kejahatan, misalnya keinginan untuk berafiliasi dengan teman sebaya, apalagi memanipulasi dari lingkungan dan hubungan dengan orang yang memiliki proses sebagai penjahat. 
Ada juga aspek penegakan peraturan. Minimnya ragam hukuman dilampaui sampai ke pelaku tindak pidana penggelapan kendaraan bermotor agar para pelaku yang sudah dibebaskan dari hukumannya tidak takut/tidak segan-segan lagi menirukan gerak-geriknya. lagi. Perangkat lunak pengaturan penjahat ini jauh lebih tidak pasti membuat para pelaku jera dalam melakukan tindakan penjahat. Susahnya mencapai keadilan bagi para penderitanya telah membuat manusia menjauh atau tidak percaya kepada Negara sebagai pelindung hak-hak warga negara.

Kemajuan teknologi, terutama media massa, turut mempengaruhi seseorang untuk berbuat jahat. Media massa menawarkan stimulus bagi pikiran seseorang dalam kehidupan sosial. Bahkan, tidak selalu aneh bagi tayangan televisi untuk memberikan contoh-contoh melakukan kejahatan, meskipun pada dasarnya tayangan tersebut tidak seharusnya memberikan contoh. Pikiran dan keserakahan listrik setiap orang tulus berbeda. Oleh karena itu, tayangan televisi dapat memberikan dampak buruk bagi seseorang.

Penyebab para pelaku melakukan tindak pidana pemalsuan yaitu disebabkan beberapa faktor internal dan eksternal sebagai berikut:

\section{1) Faktor Internal}

Faktor yang berasal dari dalam diri pelaku yang melakukan kejahatan itu sendiri, tanpa ada paksaan dari manapun. Hal ini terkait dengan keadaan mental si pelanggar. Faktor internal ini fokus kepada dasar pemikiran yang timbul secara spontan dari dalam diri.

\section{2) Faktor Eksternal}

Faktor yang berasal dari luar diri pelaku yang melakukan tindak pidana. Pada umumnya faktor ini disebabkan oleh ekonomi, lingkungan dan niat serta kesempatan yang ada untuk pelaku melakukan tindakan pidana ${ }^{6}$. hlm. 25 .

\footnotetext{
${ }^{6}$ Ridwan Hasibuan dan Ediwarman. 1995. Asas-asas Kriminologi. USU Pers, Medan.
} 
Faktor yang menyebabkan pelaku melakukan tindak pidana pemalsuan dokumen berupa STNK dalam Putusan Nomor: 241/PID.B/2021 PN Gns yaitu sebagai berikut:

\section{Faktor Ekonomi}

Faktor ekonomi yang sulit, menyebabkan seseorang melakukan tindak pidana pemalsuan surat. Untuk memenuhi kebutuhan ekonominya, seseorang rela mengerjakan pembuatan STNK palsu untuk mencari nafkah. Karena faktor ekonomi kurang baik maka pemenuhan kebutuhan sangat sulit adanya, karena itu orang-orang akan berusaha untuk dapat keluar dari himpitan ekonomi tersebut dengan cara menjadi pembuat STNK palsu. Karena dengan pekerjaan tersebut keuntungannya dapat memenuhi kebutuhan hidup sehari-hari.

2. Faktor Niat dan Kesempatan

Secara mudah dijelaskan bahwa suatu tindak pidana termasuk tindak pidana pemalsuan timbul dikarenakan dua hal yaitu adanya niat dan kesempatan. Suatu tindak pidana pemalsuan dapat dilakukan jika telah terpenuhi dua unsur yaitu niat serta adanya kesempatan untuk melakukan niat tersebut. Dalam kasus pemalsuan dokumen berupa STNK ini karena adanya faktor kesempatan yang diberikan oleh konsumen ke tersangka pembuat STNK palsu. Lalu lambat laun tersangka memanfaatkan kesempatan tersebut untuk memberikan keuntungan dengan cara menerima pesanan pembuatan STNK palsu.

1. Faktor Word Of Mouth (dari mulut ke mulut)

Faktor word of mouth atau dilingkup masyarakat biasanya disebut dari mulut ke mulut merupakan salah satu faktor yang mendorong pelaku melakukan tindak pidana pemalsuan STNK. Berawal dari satu konsumen, kemudian konsumen tersebut menyampaikan kepuasannya dalam mendapatkan STNK palsu dengan mudah, sehingga banyak memunculkan konsumen-konsumen lainnya untuk membuat STNK palsu. Hal tersebut dimanfaatkan dengan baik oleh tersangka Suradal dan Efan Efendi dengan jasa uang sebesar Rp. 150.000 (seratus 
lima puluh ribu) hinga Rp. 200.000 (dua ratus ribu rupiah) per 1 (satu) lembar STNK.

Berdasarkan uraian di atas, maka menurut peneliti yang menjadi faktor penyebab tindak pidana pemalsuan dokumen berupa STNK berdasarkan Putusan Nomor 241/PID.B/2021 PN Gns adalah karena faktor ekonomi, faktor niat dan kesempatan dan faktor dari word of mouth atau dari mulut ke mulut.

2. Pertanggungjawaban pidana terhadap pelaku tindak pidana pemalsuan dokumen berupa Surat Tanda Nomor Kendaraan (STNK) (Studi Putusan Nomor 241/PID.B/2021 PN Gns)

Tanggung jawab hukum pidana adalah tanggung jawab untuk membayar pembalasan yang akan diperoleh melalui cara pelaku kesalahan dari orang yang merugikan, tugas yang diselesaikan tidak selalu hanya terkait dengan masalah pidana tetapi juga masalah sulitnya nilai-nilai etika atau kesusilaan yang ada dalam suatu masyarakat.

Ciri regulasi adalah pemaksaan yang dilakukan melalui cara ancaman dan sanksi. Tetapi peraturan tidak selalu ditekan untuk membenarkan hal-hal yang salah, atau memaksa orang-orang yang tidak memiliki posisi dan tak tertahankan. Agar pedoman-pedoman kehidupan sosial itu benar-benar ditaati dan ditaati agar tumbuh menjadi pedoman-pedoman pidana, maka pedoman-pedoman sosial tersebut perlu dilengkapi dengan cara-cara tanpa paksaan. Dengan demikian, peraturan tersebut memiliki pedoman dan memaksa kita semua untuk mematuhi pedoman di masyarakat dan memberikan sanksi tegas kepada setiap orang yang sekarang tidak perlu lagi mematuhinya. ${ }^{7}$

Pertaggungjawaban pidana atau yang juga disebut (criminal responsibility) cara: "Seorang yang telah melakukan tindak pidana di sana tidak lagi menyarankan bahwa dia perlu dihukum, dia perlu bertindak atas gerakannya."

\footnotetext{
${ }^{7}$ Erdianto. 2012. Penyelesaian indak Pidana yang terjadi Atas tanah Sengketa-Jurnal Ilmu Hukum Vol 13, Pekanbaru, Fakultas Hukum Universitas Riau. hlm 20
} 
Menentukan suatu perbuatan untuk memutuskan apakah pelakunya tidak tepat atau sekarang tidak lagi. Dalam ide pengaturan penjahat, ada 2 (dua) bentuk kesalahan, yaitu:

a) Dolus (sengaja)

Ada teori untuk menentukan kesengajaan, yaitu:

1) teori kehendak;

2) teori pengetahuan.

b) Culpa (kelalaian)

Hal tersebut merupakan blunder secara umum, namun dalam ilmu teknologi memiliki arti teknis, khususnya suatu bentuk kejahatan yang tidak separah tindakan yang ceroboh sehingga berakibat tidak disengaja.

Di Lampung Tengah tepatnya di Kampung Surabaya Baru Kecamatan Surabaya terdapat kasus pemalsuan Surat Tanda Nomor Kendaraan (STNK). Kasus tersebut ditangani oleh Kantor Polisi Resor (Polres) Lampung Tengah karena pada waktu kejadian tersebut dilakukan di wilayah hukum Lampung Tengah. Tindak pidana pemalsuan STNK ini dilakukan oleh warga Kampung Surabaya Kabupaten Lampung Tengah yang bernama Efan Efendi dan Suradal. Efan Efendi dan Suradal melanggar Pasal 263 ayat (1) Kitab Undang-Undang Hukum Pidana.

Terdakwa I Efan Efendi bertindak bersama Terdakwa II Suradal. Berawal dari bulan November Tahun 2013, Terdakwa II Suradal belajar membuat STNK palsu di kediaman Terdakwa I Efan Efendi untuk konsumen dengan alat yang dimiliki seperti CPU, monitor, mouse, keyboard, kertas hvs dan lain-lain. Setelah belajar membuat STNK palsu, Terdakwa II merasa dirinya mulai bisa membuat STNK palsu terlihat seperti aslinya. Konsumen mengatakan STNK palsu tersebut hanya digunakan untuk mengambil uang ke leasing saja dan tidak dipergunakan untuk jalan. Kemudian konsumen merasa puas dengan hasil STNK palsu yang dibuat Terdakwa II Suradal tersebut, konsumen memberitahukan ke rekan-rekan nya bahwa ada jasa pembuatan STNK palsu maka pesanan pembuatan STNK 
palsu yang dilakukan Terdakwa I Efan Efendi dan Terdakwa II Suradal semakin ramai hingga tahun 2021 dengan ongkos sebesar Rp.25.000,- (dua puluh lima ribu rupiah) hingga Rp. 30.000,- (tiga puluh ribu rupiah). Sebelumnya kejadian ini telah dilaporkan oleh masyarakat bahwa telah adanya pemalsuan surat dan tanda tangan yang dilakukan oleh Terdakwa I dan Terdakwa II.

Para Terdakwa pada hari minggu tanggal 10 April 2021 ditangkap oleh anggota polisi dengan para saksi-saksi di kediaman Efan Efendi di Dusun IV Kampung Surabaya Baru Kecamatan Bandar Surabaya Kabupaten Lampung Tengah dan Suradal di Dusun II RT/RW Gaya Baru III Kecamatan Seputih Surabaya Kabupaten Lampung Tengah pada pukul 15.35 WIB. Dengan barang bukti handphone, keyboard, mouse, printer, monitor lcd, printer, laptop dan dokumen STNK palsu yang lainnya. Atas tindakan tersebut dapat diancam sebagaimana yang terdapat dalam KUHP Pasal 263 Ayat (1).

Dalam menjatuhkan putusan, hakim mempertimbangkan hal-hal yaitu, bahwa Para Terdakwa telah didakwa oleh Penuntut Umum dengan dakwaan Tunggal, sebagaimana diatur dalam sebagaimana diatur dalam Pasal 263 Ayat (1) KUHP Jo Pasal 55 Ayat (1) Ke- 1 KUHP yang memiliki unsur sebagai berikut: Barang siapa; Memuat surat palsu atau memalsukan surat yang dapat menimbulkan sesuatu hak, perikatan atau pembebasan utang, atau yang diperuntukkan sebagai bukti daripada sesuatu hal dengan maksud untuk memakai atau menyuruh orang lain memakai surat tersebut seolah-olah isinya benar dan tidak dipalsu; Yang melakukan, yang menyuruh melakukan dan turut seta melakukan perbuatan; Bahwa terhadap unsur-unsur tindak pidana tersebut, Majelis Hakim telah mempertimbangkan satu persatu dimana unsur "Barang Siapa" adalah subjek siapa saja, baik subjek hukum laki-laki maupun subjek hukum perempuan yang sehat jasmani dan rohaninya serta dapat dipertanggungjawabkan atas perbuatannya.

Di dalam persidangan Penuntut Umum mengajukan tuntutan sebagai berikut: 
1. Menyatakan Terdakwa I Efan Efendi dan Terdakwa II Suradal telah terbukti secara sah dan meyakinkan bersalah melakukan tindak pidana "Secara Bersama-sama Melakukan Pembuatan Surat Palsu";

2. Menjatuhkan pidana terhadap Terdakwa I Efan Efendi dan Terdakwa II Suradal, oleh karena itu dengan pidana penjara masing-masing selama 1 (satu) tahun dan 2 (dua) bulan ;

3. Menetapkan masa penahanan yang telah dijalani oleh Para Terdakwa dikurangkan seluruhnya dari pidana yang dijatuhkan;

4. Menetapkan Para Terdakwa tetap dalam tahanan;

5. Menetapkan barang bukti

Berdasarkan uraian yang telah dijabarkan diatas dapat dianalisis bahwa dengan adanya Putusan Nomor 241/PID.B/2021 PN Gns, para terdakwa telah melaksanakan pertanggungjawaban pidananya yang dimana para terdakwa masing-masing dijatuhi hukuman penjara satu tahun dua bulan oleh majelis hakim.

\section{Pertimbangan hakim terhadap pelaku tindak pidana pemalsuan dokumen berupa Surat Tanda Nomor Kendaraan (STNK) Studi Putusan Nomor 241/PID.B/2021 PN Gns}

Dalam menganalisis suatu kasus, hakim perlu mengetahui bukti-bukti, karena akibat dari pembuktian tersebut nantinya akan digunakan sebagai bahan perhatian untuk menentukan kasus. Bukti adalah tingkat yang sangat penting dalam ujian di persidangan. Penyebab pembuktian adalah untuk mencapai kebenaran bahwa suatu peristiwa/kenyataan yang dikemukakan ini pasti terjadi, sehingga seseorang dapat mencapai pilihan pilihan yang nyata dan benar. Pilihan tersebut kini tidak lagi dapat melewati sebuah pilihan sebelum itu jelas baginya 
bahwa peristiwa/kenyataan itu pasti terjadi, ini sudah teruji kebenarannya, sehingga seolah-olah ada pengadilan pidana di antara para pihak. ${ }^{8}$

Ketentuan hukum yang terus-menerus tertinggal dari keinginan dan sifat masyarakat mengharuskan hakim untuk melakukan pemeriksaan pidana yang lengkap yang dikenal dengan interpretasi pidana. Berdasarkan asas Ahmad Rifai, konsep hakim dalam menguraikan peraturan perundang-undangan dapat dibagi menjadi 2 (dua) teori, terutama asas penemuan peraturan heteronom dan asas penemuan peraturan yang berdiri sendiri. Perbedaan sederhana antara kedua teori tersebut terletak pada besarnya kepastian hakim dengan menggunakan ketentuan pidana tertulis. Asas penemuan peraturan yang heterogen menempatkan hakim sebagai corong peraturan, sedangkan asas penemuan peraturan yang mandiri menempatkan hakim pada kebebasan untuk mengakui dan menghubungkan peraturan tersebut sesuai dengan kemajuan masyarakat. ${ }^{9}$

Pilihan yang dipilih pada kasus penjahat adalah pilihan yang diturunkan dengan menggunakan pilihan setelah memilih memeriksa dan mendengar kasus penjahat terutama didasarkan pada tindakan penjahat yang tercantum dalam dakwaan. Dalam melaksanakan pidana pidana kepada terdakwa, yang dipilih tidak akan menjatuhkan pidana tanpa alat bukti yang $\operatorname{sah}^{10}$.

Dalam peraturan bajingan, mil dibagi menjadi dua, yaitu peraturan bajingan kain dan peraturan bajingan formal. Materi peraturan bajingan adalah isi dari substansi peraturan bajingan itu sendiri (KUHP). Sedangkan peraturan bajingan formal bersifat konkrit, di mana peraturan bajingan dapat mengalir atau sedang dalam proses ${ }^{11}$.

\footnotetext{
${ }^{8}$ Rahmawati, D., Siregig, I. K., \& Hasan, Z, 2021, Pertimbangan Hakim Dalam Menjatuhkan Pidana Terhadap Pelaku Tindak Pidana Pembunuhan Berencana, Widya Yuridika Jurnal Hukum, Vol.4, No.1, hlm.5

${ }^{9}$ Ahmad Rifai, 2010, Penemuan Hukum oleh Hakim dalam Perspektif Hukum Progresif, Sinar Grafika, Jakarta, hlm. 19

${ }^{10}$ Lilik Mulyadi. 2007. Hukum Acara Pidana, Citra Aditya Bakti, Bandung, hlm. 153. hlm. 19.

11 Teguh Prasetyo. 2010. Kriminalisasi dalam Hukum Pidana. Nusa Media, Bandung,
} 
Dalam memeriksa suatu perkara, yang memutuskan harus mengetahui alat bukti, karena hasil dari pembuktian tersebut nantinya akan digunakan sebagai perhatian untuk mengungkap perkara tersebut. Bukti adalah gelar yang sangat penting dalam ujian di pengadilan. Alasan pembuktian adalah untuk menuai kenyataan bahwa suatu peristiwa/kebenaran yang dikemukakan ini benar-benar terjadi, sehingga akan menuai pilihan keputusan yang nyata dan jujur. Keputusan sekarang tidak akan dapat lagi melewati suatu pilihan sebelum itu jelas baginya bahwa peristiwa/kebenaran itu benar-benar terjadi, ini adalah, itu benar, sehingga seolah-olah ada tindak pidana pacaran di antara para pihak. ${ }^{12}$

Dasar pertimbangan hukum yang diberikan oleh hakim dalam memberikan atau menjatuhkan putusan terhadap pemalsuan STNK Yang dilakukan melalui sarana Terdakwa I Efan Efendi dan Terdakwa II Suradal melalui sarana penggeledahan pada statistik penjara yang ada di persidangan, khususnya melanggar Pasal 263 Ayat (1) KUHP disamping Pasal lima puluh lima ayat (1) KUHP pertama yang memuat perincian tentang barang siapa membuat suatu surat palsu atau memalsukan suatu surat yang dapat memberikan dorongan ke atas suatu hak, suatu perikatan atau pembebasan utang, atau yang dimaksudkan sebagai pembuktian sesuatu dengan tujuan penggunaan atau menyuruh laki-laki atau perempuan lain untuk menerapkan surat itu seolah-olah isinya sudah benar dan tidak lagi dipalsukan.

Menurut Hukum Pidana Indonesia, yang dimaksud melalui sarana Unsur Siapapun adalah subjek apapun, masing-masing penjara pria dan wanita topik penjara yang sehat jasmani dan rohani dan dapat dimintai pertanggungjawaban atas perbuatannya. Bahwa Terdakwa di persidangan pada pokoknya menunjukkan bahwa identitas umum yang dicantumkan dalam surat dakwaan Penuntut Umum telah sesuai dengan para Terdakwa, selain itu banyak saksi pada pokoknya

\footnotetext{
${ }^{12}$ Alfarizy. 2021. Implementasi Pertanggungjawaban Pelaku Tindak Pidana Korupsi dalam PenyalahgunaanAnggaran Pendahuluan dan Belanja Kampung (APBK) yang di Lakukan Oleh Mantan kepala Kampung Menanga Jaya. Iblam Law Review, Vol 01 No 03. Hlm 17.
} 
menunjukkan bahwa apa yang menjadi maksud melalui cara EFAN EFENDI Bin SUTIMAN (alm) dan SURADAL Bin KROMO TUGIMIN yang saat ini sedang dihadapkan, diuji dan diadili di dalam persidangan di Pengadilan Negeri Gunung Sugih adalah milik para Tergugat. Dalam persidangan juga diketahui bahwa para Tergugat dalam keadaan sehat jasmani dan rohani, yang berarti para Tergugat telah siap dan mampu mempertanggungjawabkan setiap perbuatan yang telah mereka lakukan. Dengan demikian akan menjadi jelas bahwa apa yang dianggap melalui cara dari rincian Barangsiapa adalah Terdakwa sendiri sebagai topik penjara, akibatnya rincian utama teks ini telah terpenuhi.

Rincian "Membuat surat palsu atau memalsukan surat yang dapat memberikan dorongan ke atas untuk suatu hak, suatu penyelesaian atau keringanan utang, atau yang dimaksudkan sebagai pembuktian sesuatu dengan tujuan penggunaan atau perintah orang lain untuk menggunakan surat tersebut. seolah-olah isinya benar dan sekarang tidak lagi dipalsukan” Menimbang bahwa berdasarkan sepenuhnya pada statistik di persidangan diketahui bahwa Terdakwa Efan Efendi dan Terdakwa Suradal secara bersama-sama telah membuat STNK (Surat Tanda Nomor Kendaraan) Palsu / Tidak Asli dikeluarkan oleh SAMSAT dan Para Terdakwa membuat membuat Surat tersebut hanya seorang diri tidak ada yang membantu Para Terdakwa.

Terdakwa ditangkap oleh Anggota Polisi pada hari pada hari Minggu tanggal 10 April 2021 sekira Jam 15.35 WIB di rumah masing-masing Para Terdakwa beralamat di Kampu Surabaya Baru Kecamatan Bandar Surabaya Kabupaten Lampung Tengah; Menimbang, bahwa kejadian tersebut berawal pada saat Terdakwa Suradal membuat STNK (Surat Tanda Nomor Kendaraan) Palsu / Tidak Asli mulai dari bulan Nopember tahun 2013, sekira jam 22.30 WIB di Kamar depan rumah Terdakwa Suradal, kemudian Alat yang Terdakwa Suradal persiapkan berupa CPU, Monitor, Printer, Mose, Keyboard, kertas Hvs, tinta warna, Carter, gunting dan lain - lainya, selanjutnya Terdakwa Suradal mulai belajar untuk membuat STNK (Surat Tanda Nomor Kendaraan) Palsu / Tidak Asli 
dan setelah Terdakwa Suradal mulai bisa membuat STNK (Surat Tanda Nomor Kendaraan) Palsu / Tidak Asli dan terlihat seperti aslinya maka selanjutnya setelah Terdakwa Suradal buatkan Konsumen tersebut merasa puas dan senang, konsumen tersebut memberikan sejumlah uang, kepada Terdakwa Suradal sebesar Rp15.000,00 (lima belas ribu rupiah). selanjutnya konsumen tersebut mengatakan kepada Terdakwa Suradal jika STNK (Surat Tanda Nomor Kendaraan) Palsu / Tidak Asli hanya di gunakan untuk ngambil uang ke Leasing saja tidak untuk jalan, kemudian setelah Terdakwa Suradal merasa mampu membuat STNK (Surat Tanda Nomor Kendaraan) Palsu / Tidak Asli Terdakwa Suradal bisa maka, lambat laut dan berjalanya waktu hingga tahun 2021 hingga saat ini, di karenakan kemungkinan konsumen tersebut memberi tahu, kepada teman-temanya atau yang lainya maka Terdakwa Suradal membuat STNK (Surat Tanda Nomor Kendaraan) Palsu / Tidak Asli tambah ramai yang meminta tolong kepada Terdakwa Suradal akhirnya Terdakwa Suradal memintai ongkos atau Jasa uang sebesar Rp25.000,00 (dua puluh lima ribu rupiah) hingga sebesar Rp30.000,00 (tiga puluh ribu rupiah). Adapun STNK (Surat Tanda Nomor Kendaraan) Palsu / Tidak Asli tersebut Terdakwa Efan Efendi pesan dari Terdakwa Suradal melalui Whatsapp dengan mengirimkan Nomor rangka dan Nomor mesin kendaraan Kemudian setelah Terdakwa Efan Efendi merasa mampu memesan STNK (Surat Tanda Nomor Kendaraan) Palsu / Tidak Asli Terdakwa Efan Efendi bisa maka lambat laut dan berjalanya waktu hingga tahun 2021 hingga saat ini, di karenakan kemungkinan orang tersebut memberi tahu kepada temantemanya atau yang lainya maka Terdakwa Efan Efendi membuat STNK (Surat Tanda Nomor Kendaraan) Palsu / Tidak Asli tambah rame, yang meminta tolong kepada Terdakwa Efan Efendi akhirnya Terdakwa Efan Efendi memintai ongkos atau Jasa uang sebesar Rp150.000,00 (seratus lima puluh ribu rupiah) hingga sebesar Rp200.000,00 (dua ratus ribu rupiah). Sepengetahuan Terdakwa Efan Efendi jumlah keuntungan Global yang telah Terdakwa Efan Efendi peroleh dari Jasa yang telah Terdakwa Efan Efendi jual untuk kepentingan Orang lain selama kurun waktu 4 (empat) 
Bulan kurang lebih sebesar Rp2.500.000,00 (dua juta lima ratus ribu rupiah) dan uang tersebut Terdakwa Efan Efendi pergunakan untuk keperluan hidup seharihari, hingga akhirnya Terdakwa Efan Efendi dan Terdakwa Suradal berhasil ditangkap oleh pihak Kepolisian; Menimbang, bahwa STNK palsu yang Para Terdakwa buat memiliki perbedaan dengan STNK yang asli antara lain Kertas pada STNK palsu dengan yang STNK asli berbeda dan Warna yang ada pada STNK palsu berbeda dengan warna yang ada pada STNK asli, STNK palsu tidak memiliki hologram, sedangkan STNK yang asli terdapat hologram.

Berdasarkan keterangan yuridis yang ditemukan di persidangan, ternyata terbukti bahwa rekayasa perbuatan Terdakwa pada saat itu berubah menjadi bahwa Tergugat telah membuat STNK (Surat Nomor Kendaraan) palsu/tidak asli yang diterbitkan dengan bantuan penggunaan SAMSAT, dengan demikian rincian kedua dari buletin ini telah terpenuhi.

Dalam menilai kebenarannya, putusan memeriksa keterangan para saksi dan terdakwa. Sedangkan gerak-gerik Terdakwa I Efan Efendi dan Terdakwa II Suradal meresahkan masyarakat umum dan merugikan saksi penderita Siti Mutmainah, para Tergugat secara terang-terangan mengakui gerak-geriknya dan menyayangkan gerak-geriknya dan para terdakwa sama sekali tidak dihukum.

Setiap masyarakat membutuhkan pilihan keputusan yang jujur, namun hakim sebagai manusia biasa tidak dapat memenuhi semua pihak. Meski begitu, keputusan diprediksi sebagai cara untuk membuat pilihan yang sepenuhnya benar terutama berdasarkan informasi di persidangan berdasarkan peraturan yang berlaku. Namun setidaknya putusan hakim bisa dirasakan para pencari keadilan.

\section{Penutup}

Faktor penyebab pelaku melakukan tindak pidana pemalsuan STNK yaitu faktor ekonomi yang menggiring keinginan pelaku untuk mendapatkan keuntungan dari tindak pidana pemalsuan STNK yang dilakukannya, yang dalam hal ini memperoleh keuntungan dalam kurun waktu 4 (empat) bulan sebesar Rp. 
2.500.000,00 (dua juta lima ratus ribu rupiah) yang digunakan untuk memenuhi keperluan hidup sehari-hari. Faktor niat dan kesempatan juga mendukung pelaku tetap melakukan tindak pidana pemalsuan serta faktor penyampaian dari mulut ke mulut ikut serta mensukseskan para pelaku melakukan tindak pidana pemalsuan STNK.

Pertanggungjawaban pidana yang dijatuhkan kepada para terdakwa yang dimana para terdakwa masing-masing dijatuhi hukuman penjara satu tahun dua bulan oleh majelis hakim dan membayar biaya perkaran masing-masing sebesar Rp. 2.000,00 (dua ribu rupiah).

Pertimbangan hakim dalam menjatuhkan hukuman, hakim melihat dari keterangan para saksi dan terdakwa. Menimbang bahwa perbuatan Terdakwa I Efan Efendi dan Terdakwa II Suradal meresahkan masyarakat dan merugikan saksi korban Siti Mutmainah, para Terdakwa mengakui terus terang perbuatannya dan menyesali perbuatannya serta para terdakwa belum pernah dihukum.

\section{Daftar Pustaka}

Adami Chazawi dan Ardi Ferdian, Tindak Pidana Pemalsuan : Tindak Pidana Yang Menyerang Kepentingan Hukum Terhadap Kepercayaan Masyarakat mengenai Kebenaran Isi Tulisan dan Berita yang Disampaikan, (Jakarta: PT Rajawali Pers, 2014), hlm 135.

Ahmad Rifai, 2010, Penemuan Hukum oleh Hakim dalam Perspektif Hukum Progresif, Sinar Grafika, Jakarta, hlm. 19

Alfarizy. 2021. Implementasi Pertanggungjawaban Pelaku Tindak Pidana Korupsi dalam PenyalahgunaanAnggaran Pendahuluan dan Belanja Kampung (APBK) yang di Lakukan Oleh Mantan kepala Kampung Menanga Jaya. Iblam Law Review, Vol 01 No 03.

Ali, M. 2017. Sistem Peradilan Pidana Progresif; Alternatif dalam Penegakan Hukum Pidana. Jurnal hukum Ius Quia Iustum, Vol.14, No. 2. 
Erdianto. 2012. Penyelesaian indak Pidana yang terjadi Atas tanah SengketaJurnal Ilmu Hukum Vol 13, Pekanbaru, Fakultas Hukum Universitas Riau.

I.S Susanto, Kriminologi, cet. Ke 1, (Yogyakarta: Genta Publising, 2011), hlm 22.

Kitab Undang-Undang Hukum Pidana

Kitab Undang-Undang Hukum Acara Pidana

Lilik Mulyadi. 2007. Hukum Acara Pidana, Citra Aditya Bakti, Bandung, hlm. 153.

Putusan Pengadilan Negeri Gunung Sugih Nomor 241/Pid.B/2021/Pn.Gns

Rahmawati, D., Siregig, I. K., \& Hasan, Z, 2021, Pertimbangan Hakim Dalam

Menjatuhkan Pidana Terhadap Pelaku Tindak Pidana Pembunuhan

Berencana, Widya Yuridika Jurnal Hukum, Vol.4, No.1

Ridwan Hasibuan dan Ediwarman. 1995. Asas-asas Kriminologi. USU Pers, Medan. hlm. 25.

Teguh Prasetyo. 2010. Kriminalisasi dalam Hukum Pidana. Nusa Media, Bandung, hlm. 19.

Undang-Undang Dasar Negara Republik Indonesia Tahun 1945 Hasil Amandemen keempat.

Undang-Undang Nomor 22 Tahun 2009 Tentang Lalu Lintas dan Angkutan Jalan 